\title{
CHARACTERIZATION OF $\beta$-GALACTOSIDASE FROM LACTOBACILLUS ACIDOPHILUS: STABILITY AND KINETIC STUDY
}

Milica B. Carević*, Maja S. Vukašinović-Sekulić, Katarina M. Banjanac, Ana D. Milivojević, Marija M. Ćorović, Dejan I. Bezbradica

Department of Biochemical Engineering and Biotechnology, Faculty of Technology and Metallurgy, University of Belgrade, Belgrade, Serbia

$\beta$-Galactosidase is the industrially important enzyme that catalyzes both, lactose hydrolysis and synthesis of different bioactive galactosides. In this study, optimal conditions (fermentation temperature, inoculum concentration and lactose concentration) for accomplishing high yields of $\beta$-galactosidase activity from Lactobacillus acidophilus ATCC 4356, bacteria regarded as safe for human consumption, were investigated. Using the response surface methodology (RSM), it was concluded that the highest activity and specific activity were obtained by 2-day shake-flask culture fermentation at $28{ }^{\circ} \mathrm{C}$, provided that the lactose content in the fermentation medium was $1.48 \%$, and the inoculum concentration was $2.8 \%$. The optimum temperature and $\mathrm{pH}$ for the obtained enzyme were $45^{\circ} \mathrm{C}$ and 6.5 , respectively. More importantly, these conditions simultaneously ensure a high enzyme stability. The $\mathrm{K}_{\mathrm{m}}$ and $\mathrm{V}_{\max }$ values were $0.44 \mathrm{mM}$ and $25.64 \mathrm{mM} / \mathrm{h}$ (for o-nitrophenyl- $\beta$-D-galactopyranoside), and $3.79 \mathrm{mM}$ and $3.10 \mathrm{mM} / \mathrm{h}$ (for lactose), and the substrate excess inhibition was not observed. On the other hand, the enzyme was inactivated in the presence of $\mathrm{Ca}^{2+}, \mathrm{Ba}^{2+}$, and $\mathrm{Cu}^{2+}$.
(ORIGINAL SCIENTIFIC PAPER) UDC 577.152.3:579.86:547.458.5

Keywords: $\beta$-galactosidase, Lactobacillus acidophilus, enzyme production, response surface methodology

\section{Introduction}

$\beta$-Galactosidase (EC 3.2.1.23), the enzyme responsible for the hydrolysis of lactose and other structurally related compounds, is widely used in the dairy industry for lactose hydrolysis in milk and whey, resulting in the facilitation of digestibility and in the improvement of technological and sensorial characteristics in sweetened, condensed and frozen dairy products $[1,2]$. Besides, in food processing, $\beta$-galactosidase is a valuable biocatalyst for environmental biotechnology since it solves the problem of whey utilization and disposal [3]. Recently, much attention has been drawn to prospective uses of this enzyme to catalyze transgalactosylation reactions where galactose moiety is transferred to an acceptor that is not water, but another sugar, alcohol, or some aromatic glucoside, leading to the production of different bioactive galactosides [4-6]. The interest in galactosides and their synthesis has been considerably increased during the last decades, namely in the field of galacto-oligosaccharides (GOS) synthesis [7-10], due to their exceptional physicochemical and physiological characteristics [11-13]. GOS are nondigestible oligosaccharides and are considered to be a prebiotic food, as it was found that they promote the growth and establishment of human intestinal microbiota, while simultaneously suppressing potentially harmful bacteria [1315]. Furthermore, the potential beneficial effect on the human host such as reduction of the cholesterol level in blood serum, colon cancer prevention and enhancement of mineral absorption assure its prosperous application in the pharmaceutical industry $[16,17]$.

$\beta$-Galactosidase is a widespread enzyme that can be found in plants, animal organs and microorganisms. Amongst them, microbial sources are the most preferable ones due to easy production, high activities and good stability of the enzyme. Enzymes from yeasts are prevalently used in milk lactose hydrolysis due to their neutral $\mathrm{pH}$ optimums, while fungal (mainly Aspergillus $\mathrm{sp}$.) galactosidases with acidic $\mathrm{pH}$ optimums prevail in whey hydrolysis $[1,2]$. On the other hand, although numerous bacteria synthesize this enzyme, the industrial usage of bacterial $\beta$-galactosidases is scarce due to the fact that a few bacteria are regarded as a safe source [18-20]. Therefore, in recent years, lactic acid bacteria (LAB) have attracted great interest mostly because of their GRAS (generally recognized as safe) status, which allows the use of crude enzyme extracts, without the necessity of performing tedious purification protocols [21]. Among $L A B$, significant attention is attributed to Lactobacillus acidophilus since it has probiotic properties and, more importantly, produces a significant galactosidase activity [22-24]. The aim of this study was to increase the utilization of $\beta$-galactosidase activity of strain $L$. acidophiIus ATCC 4356 by the improvement of its fermentative

\footnotetext{
* Author address: Milica Carević, Faculty of Technology and Metallurgy, University of Belgrade, Karnegijeva 4, 11000 Belgrade, Serbia

E-mail: mcarevic@tmf.bg.ac.rs

The manuscript received: February, 28, 2017.

Paper accepted: April,10, 2017.
} 
production and the examination of key properties of interest for its industrial application. Hence, the initial experimental stage was focused on identifying the optimal culture conditions for $\beta$-galactosidase production using a response surface methodology (RSM). Further on, a detailed characterization in terms of thermal/pH activity and stability, as well as kinetics parameters determination of the obtained enzyme was carried out.

\section{Experimental}

\section{Materials}

Throughout this study, L. acidophilus ATCC 4356 obtained from the American Type Culture Collection (ATCC, Rockville, USA) was used for $\beta$-galactosidase production. The components of cultivation media were purchased from Torlak Institute of Immunology and Virology (Belgrade, Serbia). The substances used as enzyme substrates were o-nitrophenyl- $\beta$-D-galactopyranoside (o-NPG) and lactose (Sigma Aldrich, St. Louis, USA). For the determination of the glucose concentration, the GOD/POD assay kit purchased from Chronolab (Zug, Switzerland) was employed. Other chemicals were of analytical grade and purchased from Centrohem (Stara Pazova, Serbia), unless specified otherwise.

\section{Optimization of fermentation conditions}

Fermentations were performed as batch cultures in erlenmeyer flasks with modified de Man, Rogosa and Sharpe (MRS) culture medium, containing lactose instead of glucose, under microaerophilic conditions for 2 days. The experiments were conducted using a central composite rotatable design consisting of 14 experimental runs plus six replicates on the central point (Table 1). The experimental factors were analyzed in the following ranges: temperature $\left(X_{1}, 26.6-43.4{ }^{\circ} \mathrm{C}\right)$, inoculum concentration $\left(\mathrm{X}_{2}, 2.8-11.2 \%\right)$ and lactose concentration $\left(X_{3}, 1.48-6.52 \%\right)$, and the factors and their ranges were chosen on the basis of preliminary conducted experiments [22]. In our study, two response variables were measured: overall $\beta$-galactosidase activity $(\mathrm{IU} / \mathrm{ml})$ and specific $\beta$-galactosidase activity (IU/mg proteins). The data obtained were analyzed by a response surface method (RSM) to fit the second-order polynomial equation (Equation 1):

$Y=b_{0}+\sum_{i=1}^{5} b_{i} X_{i}+\sum_{i=1}^{5} b_{i i} X_{i}^{2}+\sum_{i, j, i\langle j}^{5} b_{i j} X_{i} X_{j} \ldots \ldots \ldots$

where $\mathrm{Y}$ is the response variable (lactose conversion degree and product concentration), bo, bi, bii, bij, are the regression coefficients, and $X_{i}$ and $X_{j}$ are independent variables. The least-squares method was employed for the response function coefficient calculation and their statistical significance evaluation. Only the significant terms $(p \leq 0.05)$ were considered for the final reduced model. The adequacy of the obtained model was determined by the Fisher test. Student t-test was used to confirm the significance of the factor studied. MATLAB 7.0
(Mathworks Inc., Natrick, USA) was used for this purpose.

Extraction of intracellular $\beta$-galactosidase

In order to obtain $\beta$-galactosidase from $L$. acidophilus, after the fermentation microbial cells were harvested by centrifugation (Sigma ${ }^{\circledR} 2-16$, SciQuip Ltd, Shropshire, UK) at $12000 \mathrm{rpm}$ for $10 \mathrm{~min}$. Then, after being washed twice with $0.1 \mathrm{M}$ sodium phosphate buffer $(\mathrm{pH} 6.8)$, they were re-suspended in the same buffer and subjected to vigorous vortexing in the presence of quartz sand $(150 \mu \mathrm{m})$ in order to achieve cell disruption [22]. The activity of the released $\beta$-galactosidase was measured after removing cell debris by centrifugation (12000 rpm for $5 \mathrm{~min}$ ).

\section{$\beta$-Galactosidase assays}

To determine $\beta$-galactosidase activity $10 \mathrm{mM}$ o-NPG in $0.1 \mathrm{M}$ phosphate buffer $(\mathrm{pH} 6.8)$ was used as a substrate. The reaction was allowed to proceed at least 2 minutes, while o-nitrophenol (o-NP) released in the reaction was measured spectrophotometrically (Ultrospec 3300 pro, Amersham Biosciences, Freiburg, Germany) each 30 seconds at $410 \mathrm{~nm}$ and the activity was determined from the slope of a constructed graph. One unit (IU) is defined as the amount of the enzyme that catalyzes the liberation of $1 \mu \mathrm{mol}$ o-NP per min under the assay conditions. The molar extinction coefficient for o-NP was determined to be $1357 \mathrm{dm}^{3} \cdot \mathrm{mol}^{-1} \cdot \mathrm{cm}^{-1}$ ). The concentration of proteins in cell extracts was determined according to the procedure of Bradford using bovine serum albumin as the standard protein [25].

Effects of temperature and $\mathrm{pH}$ on enzymatic activity and stability

The effect of temperature on $\beta$-galactosidase activity was examined by incubation of the enzyme and the substrate $(10 \mathrm{mM}$ o-NPG in $0.1 \mathrm{M}$ sodium phosphate buffer $\mathrm{pH}$ 6.8) at temperatures ranging from 30 to $60^{\circ} \mathrm{C}$. Also, the effect of $\mathrm{pH}$ was determined on $45^{\circ} \mathrm{C}$ by varying buffers used for the substrate preparation. Sodium acetate buffer ( $\mathrm{pH}$ 4.0-5.5) and sodium phosphate buffer ( $\mathrm{pH}$ 6-8) were used for this purpose. The enzyme activity measurement was conducted in the previously described manner.

On the other hand, in order to determine the thermal stability of the enzyme, the enzyme was incubated at different temperatures from 50 to $60{ }^{\circ} \mathrm{C}$ during several hours. Retained enzyme activity (\%) was measured at appropriate time intervals using the previously described method. Similarly, the pH stability of the enzyme was examined by incubating the enzyme in different buffers $(\mathrm{pH}$ 4-8) for several hours, and the retained enzyme activity was measured in appropriate time intervals.

Effects of different cations on $\beta$-galactosidase activity The effect of various cations $\left(\mathrm{Na}^{+}, \mathrm{K}^{+}, \mathrm{Mg}^{2+}, \mathrm{Ca}^{2+}, \mathrm{Ba}^{2+}\right.$, $\mathrm{Cu}^{+}, \mathrm{Zn}^{2+}$ ) on $\beta$-galactosidase activity was examined as previously described, provided that appropriate chloride salts were added to the substrate solution (10 mM o-NPG in $0.1 \mathrm{M}$ sodium phosphate buffer $\mathrm{pH} 6.8$ ) to reach final 
concentrations of $1 \mathrm{mM}, 10 \mathrm{mM}$, and $100 \mathrm{mM}$. The obtained results are presented as relative activity (\%), with regard to the enzyme activity without added salts. All experiments were performed in triplicate, and the mean values are presented graphically.

\section{Determination of enzyme kinetic parameters}

In order to determine the kinetic parameters, two enzymatic reactions, namely lactose and o-NPG hydrolysis, were observed. These reactions were conducted under conditions similar to the previously described manner, using o-NPG (0-20 mM) and lactose (0-500 mM) as substrates in $0.1 \mathrm{M}$ sodium phosphate buffer $(\mathrm{pH} 6.8)$. The concentration of the released o-NP was calculated by the previously described method, while the released glucose concentration was determined using the glucose oxidase/peroxidase (GOD/POD) assay kit. The observed results were fitted with linear regression to LineweaverBurk equation in order to calculate $\mathrm{Km}$ and $\mathrm{V}_{\text {max }}$.

\section{Results and discussion}

\section{Optimization of $\beta$-galactosidase production}

Experimental designs and RSM represent an important tool that is nowadays widely used in defining optimal process conditions, since it shows numerous advantages over conventional methods by being able to determine not just the effects of different factors on the enzyme production, but at the same time to give an insight into their mutual interactions [26]. In this study RSM was used to determine optimal values of relevant fermentation factors, namely temperature $\left(X_{1}\right)$, inoculum $\left(X_{2}\right)$ and the lactose concentration $\left(X_{3}\right)$. These exact factors were chosen on the basis of our previous findings, highlighting the importance of lactose in enzyme induction [22]. However, the optimization of the lactose concentration represents a rather difficult task, since lactose promotes the enzyme synthesis. Yet, high lactose concentrations and a significant production of glucose can cause the enzyme synthesis repression. Therefore, in view of maximizing the $\beta$-galactosidase production, the lactose concentration and relevant related factors (temperature and inoculum size) were examined, taking into consideration their individual and combined effects.

The experimental plan consisting of 20 randomly performed experiments (Table 1) was applied, and two output variables, namely $\beta$-galactosidase activity $(\mathrm{IU} / \mathrm{ml})$ and specific $\beta$-galactosidase activity (IU/mg proteins) were measured. At the beginning, in terms of determining the optimum conditions for achieving the highest $\beta$-galactosidase activity $(\mathrm{IU} / \mathrm{ml})$ yields, the results of these experiments were analyzed. The adequacy of fitting the obtained results with the second-order model (Equation 1) was analyzed using Fischer test. Since it was concluded that the model properly describes experimental results $(F=2.12)$, the Student test was performed in view of analyzing the significance of factors and their interactions.
Table 1. Experimental plan for RSM (including coded and real values of variables) and experiment results.

\begin{tabular}{cccccc}
\hline Run & $\begin{array}{c}\text { Temperature } \\
\left({ }^{\circ} \mathbf{C}\right)\end{array}$ & $\begin{array}{c}\text { Inoculum } \\
\text { concentration } \\
(\%)\end{array}$ & $\begin{array}{c}\text { Lactose } \\
\text { concentration } \\
(\%)\end{array}$ & $\begin{array}{c}\text { Activity } \\
\text { (IU/mI) }\end{array}$ & $\begin{array}{c}\text { Specific } \\
\text { activity } \\
\text { (IU/mg } \\
\text { proteins) }\end{array}$ \\
\hline 1 & $-1(30)$ & $-1(4.5)$ & $-1(2.5)$ & 2.892 & 2.419 \\
2 & $1(40)$ & $-1(4.5)$ & $-1(2.5)$ & 1.882 & 0.827 \\
3 & $-1(30)$ & $1(9.5)$ & $-1(2.5)$ & 1.561 & 1.350 \\
4 & $1(40)$ & $1(9.5)$ & $-1(2.5)$ & 2.295 & 1.116 \\
5 & $-1(30)$ & $-1(4.5)$ & $1(5.5)$ & 1.974 & 1.233 \\
6 & $1(40)$ & $-1(4.5)$ & $1(5.5)$ & 1.469 & 0.985 \\
7 & $-1(30)$ & $1(9.5)$ & $1(5.5)$ & 1.606 & 0.906 \\
8 & $1(40)$ & $1(9.5)$ & $1(5.5)$ & 1.239 & 0.584 \\
9 & $-1.682(26.6)$ & $0(7)$ & $0(4)$ & 2.341 & 1.224 \\
10 & $1.682(43.4)$ & $0(7)$ & $0(4)$ & 0.837 & 0.352 \\
11 & $0(35)$ & $-1.682(2.8)$ & $0(4)$ & 2.662 & 1.396 \\
12 & $0(35)$ & $1.682(11.2)$ & $0(4)$ & 2.387 & 1.247 \\
13 & $0(35)$ & $0(7)$ & $-1.682(1.48)$ & 2.570 & 1.322 \\
14 & $0(35)$ & $0(7)$ & $1.682(6.52)$ & 1.515 & 0.761 \\
15 & $0(35)$ & $0(7)$ & $0(4)$ & 1.974 & 1.205 \\
16 & $0(35)$ & $0(7)$ & $0(4)$ & 2.111 & 1.111 \\
17 & $0(35)$ & $0(7)$ & $0(4)$ & 2.295 & 1.069 \\
18 & $0(35)$ & $0(7)$ & $0(4)$ & 2.092 & 1.419 \\
19 & $0(35)$ & $0(7)$ & $0(4)$ & 1.882 & 0.970 \\
20 & $0(35)$ & $0(7)$ & $0(4)$ & 2.360 & 1.350 \\
\hline & & & & & \\
\hline
\end{tabular}

After the subsequent elimination of insignificant coefficients, following the regression model for the produced $\beta$-galactosidase activity was derived (Equation 2).

$Y_{1}(I U / m l)=1.870-0.244 X_{1}-0.124 X_{2}-$

$-0.287 X_{3}-0.220 X_{1}^{2}+0.203 X_{1} X_{2}$

As it can be clearly seen from the equation, all linear regression coefficients are significant, thus it can be concluded that all examined factors have the significant influence on the produced $\beta$-galactosidase activity. However, there is only one significant quadratic coefficient $\left(\beta_{11}=-0.220\right)$. Hence, the effect of temperature $\left(X_{1}\right)$ can be presented with quadratic function with maximum (Figure 1A), since the quadratic coefficient has a negative value. On the other hand, the effect of inoculum and lactose concentration are represented only with negative linear coefficients, leading to a continuous straight line decrease of the $\beta$-galactosidase activity yield with the increase of these two factors (Figure 1B).

Also, a positive interaction between the temperature and inoculum concentration can be observed $\left(\beta_{12}=0.203\right)$, causing a shift of the local temperature optimum towards lower values, with the decrease of the inoculum concentration (Figure 1C). Namely, at lower inoculum concentrations, the temperature optimum, in respect to the produced overall activity, is around $28^{\circ} \mathrm{C}$. However, when the inoculum concentration increases, the optimum temperature rises considerably. In view of this, the highest $\beta$-galactosidase activities are achieved when fermentation is performed at $28{ }^{\circ} \mathrm{C}$, with $1.48 \%$ lactose in the fermentation medium, and provided that the inoculum concentration is around $2.8 \%$. 


\section{Figure 1A}

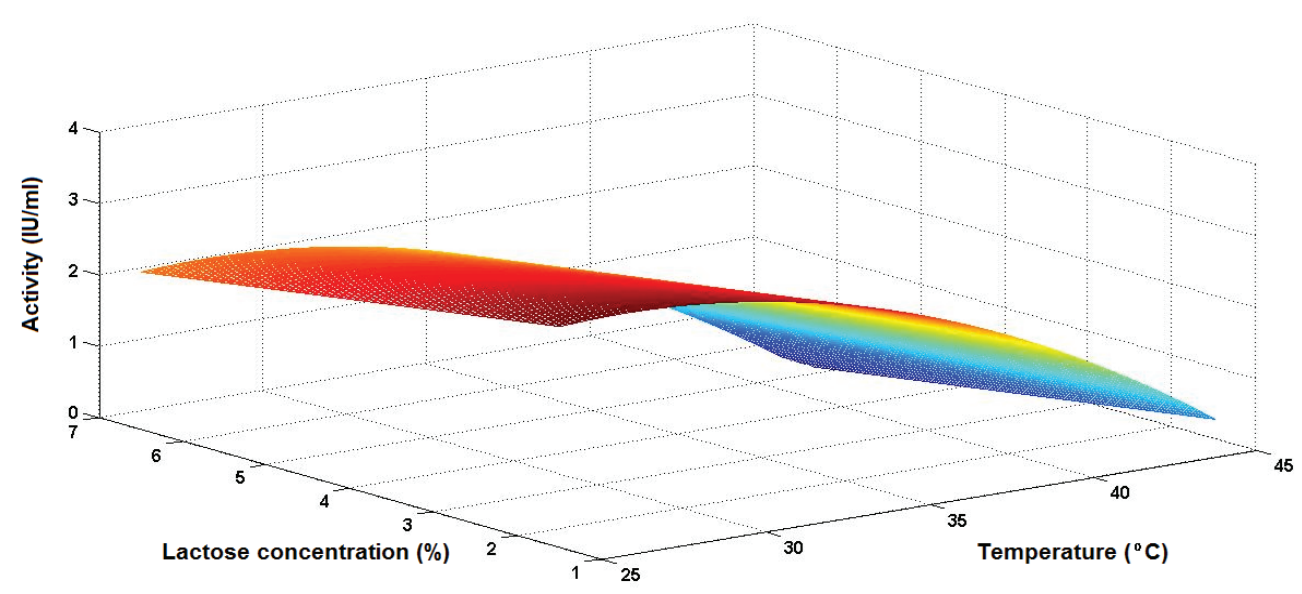

Figure 1B

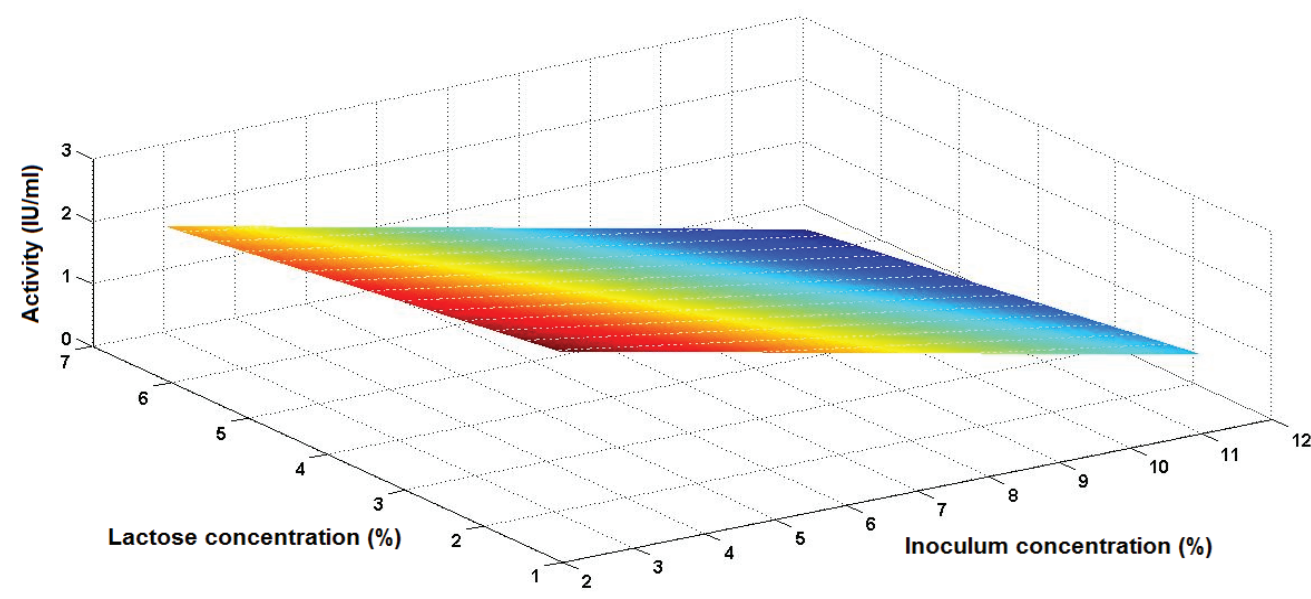

Figure 1C

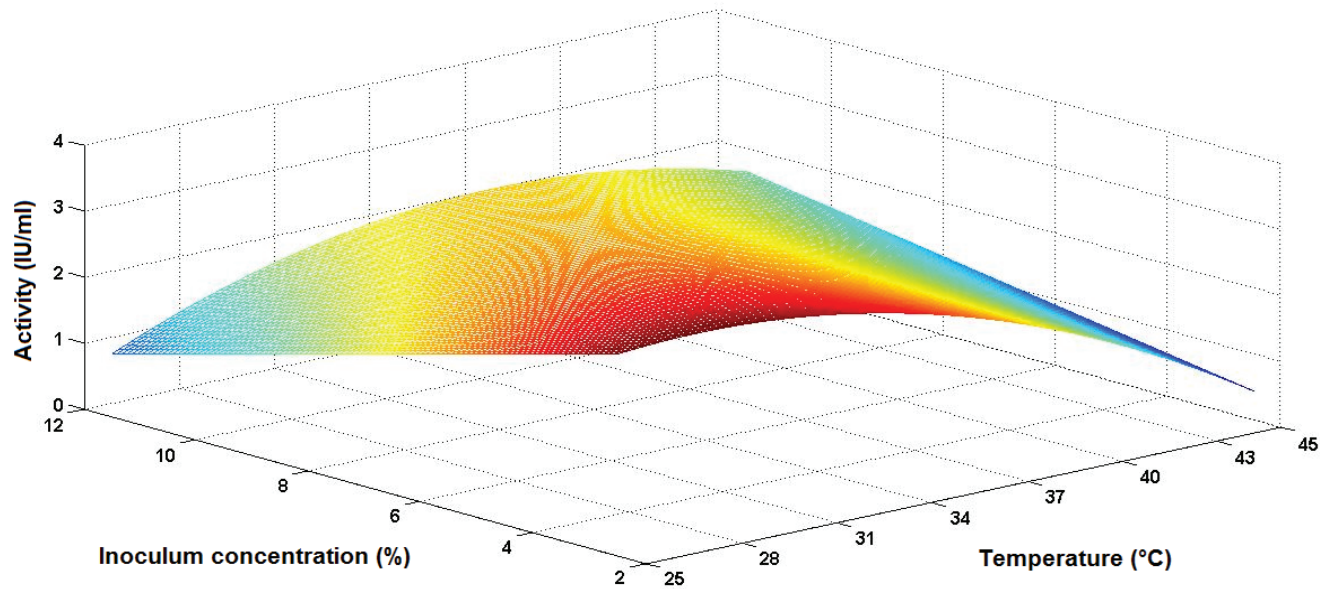

Figure 1. The response surface plots: $(A)$ Interactive effect of the lactose concentration and temperature on the produced $\beta$-galactosidase activity. The inoculum concentration was fixed at: $X_{2}=0$. (B) Interactive effect of lactose and inoculum concentration on the produced $\beta$-galactosidase activity. The temperature was fixed at: $X_{1}=0$. (C) Interactive effect of inoculum concentration and the temperature on the produced $\beta$-galactosidase activity. The lactose concentration was fixed at: $X_{3}=0$. 
Since this microorganism produces a wide variety of different enzymes, the influence of the same experimental factors on the produced specific activity (IU/mg proteins) was examined in the subsequent step. After undertaking the same analysis, the significant regression model $(F=1.76)$ for the other examined output variable was derived (Equation 3).

$Y_{1}(I U / m g)=0.993-0.237 X_{1}-0.110 X_{2}-0.185 X_{3}-$

$-0.085 X_{1}^{2}+0.137 X_{1} X_{2}+0.135 X_{1} X_{3}$

Figure 2A

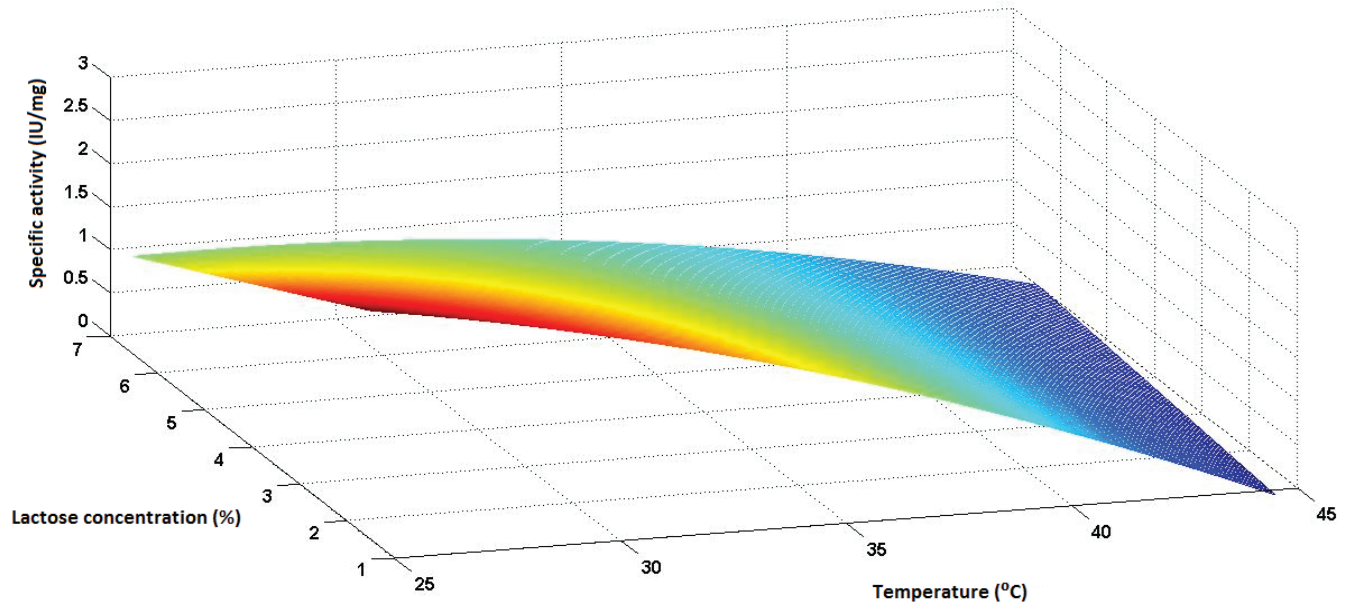

Figure 2B

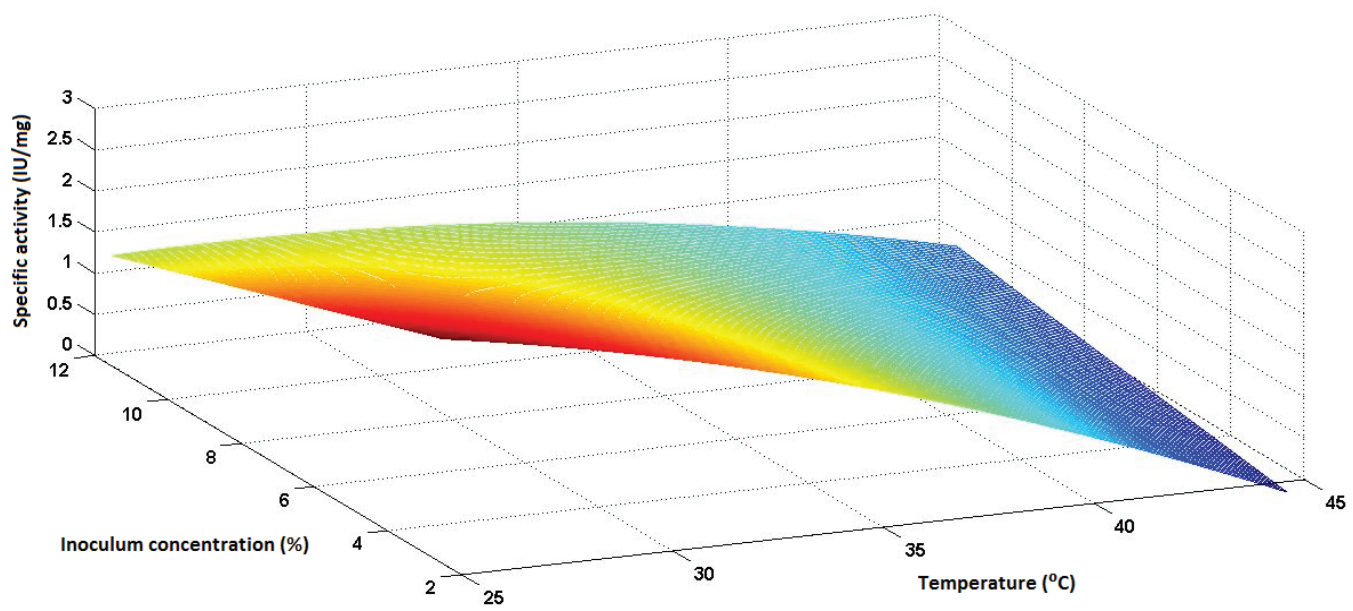

Figure 2. The response surface plots: (A) Interactive effect of the lactose concentration and temperature on the specific $\beta$-galactosidase activity. The inoculum concentration was fixed at: $X_{2}=0$. (B) Interactive effect of inoculum concentration and the temperature on specific $\beta$-galactosidase activity. The lactose concentration was fixed at: $\mathrm{X}_{3}=0$.

Therefore, in the model for a specific activity combined effect of two interactions (temperature and inoculum concentration and temperature and lactose concentration) caused an additional shift of temperature optimums towards even lower temperature values (around $25^{\circ} \mathrm{C}$ ) (Figure 2B). These results can be explained by the intensive synthesis of other enzymes on higher temperatures, and therefore, the optimum values of examined param-
Clearly, the obtained model demonstrates a similar trend with respect to the previously derived one, since all except one of the coefficients are present in both equations. The discrepancy between the models is in the presence of a positive interaction between the temperature and lactose concentration in the model considering specific $\beta$-galactosidase activity as the output (Figure $2 \mathrm{~A}$ ). 
produced activity and specific activity were $3.12 \mathrm{IU} / \mathrm{ml}$ and $2.64 \mathrm{lU} / \mathrm{mg}$ proteins. Bearing in mind that these results are within $5 \%$ deviation from the predicted values, it can be concluded that the model ensures a good prediction.

Interestingly, the observed optimum lactose (1.48\%) and inoculum concentration $(2.8 \%)$ are considerably lower than in previously reported optimization studies $[27,28]$. This can be possibly explained by the fact that L. acidophilus is more susceptible to excess lactose, and consequently glucose repression than other tested microorganisms. Also, it can be ascribed to a more complex approach in the experiment planning, recognizing the effects of all parameters and their interactions, hence low lactose optimum can also be due to the simultaneous low optimum inoculum concentration.

Effect of Temperature and pH on Enzyme Activity and Stability

Enzyme characteristics can vary greatly depending on the source. For example, the majority of enzymes originating from lactic acid bacteria are mesophilic enzymes active at ambient temperatures and in the neutral $\mathrm{pH}$ surroundings, yet, this may differ from strain to strain. The $\beta$-galactosidase from $L$. acidophilus obtained in our study showed the highest activity at temperatures around $45^{\circ} \mathrm{C}$ and around $\mathrm{pH}$ values of 6.8 . These results are consistent with the literature data for $\mathrm{LAB} \beta$-galactosidases, bearing in mind that the reported optimal temperatures are in the range $40-55^{\circ} \mathrm{C}[18,27$, 29], and the optimal $\mathrm{pH}$ values are neutral (between 6.5 and 7.5$)[23,24]$. However, the optimal conditions with respect to their activity do not often coincide with the conditions ensuring long-lasting stability of the enzyme. Therefore, notable attention should be paid to this particular matter.

Figure 3A

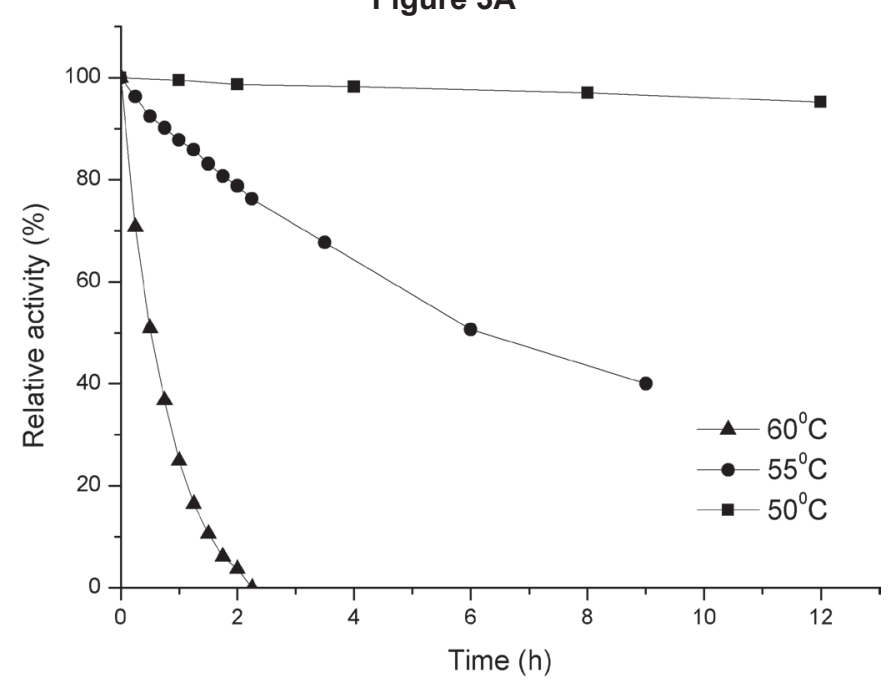

Figure 3B

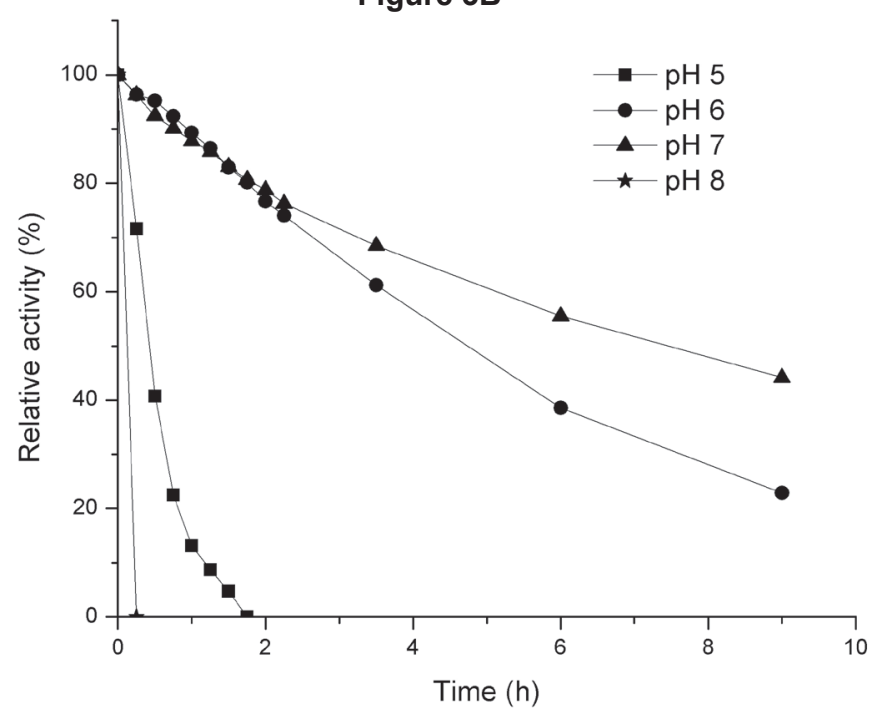

Figure 3. Stability study of $\beta$-galactosidase from Lactobacillus acidophilus: (A) thermal stability, (B) $\mathrm{pH}$ stability

In terms of the temperature stability assessment, the obtained crude enzyme was incubated at elevated temperatures $\left(50-60{ }^{\circ} \mathrm{C}\right)$, and the residual relative activity was measured during the time course (Figure $3 \mathrm{~A}$ ). The rapid decrease in the enzyme stability can be noted with the temperature increment. More precisely, the enzyme shows the greatest stability when incubated at $50{ }^{\circ} \mathrm{C}$, wherein after 12 hours the enzyme activity is almost unchanged. On the other hand, the inactivation was more pronounced at higher temperatures, and a complete loss of the enzyme activity took place after only $2 \mathrm{~h}$ at $60{ }^{\circ} \mathrm{C}$. From Figure 3, it can be observed that inactivation occurred in one step, indicating that no conformational changes within the enzyme took place during the observed period. Inactivation kinetics, therefore, can be well described with the exponential model, and inactivation parameters, namely inactivation constant ( $k d, 1 / h)$ and enzyme half-lives (t1/2, h) on the tested temperatures can be calculated. As it can be seen from Table 2 , the enzyme half-lives obtained at $50{ }^{\circ} \mathrm{C}, 55^{\circ} \mathrm{C}$ and $60^{\circ} \mathrm{C}$ are $138.6 \mathrm{~h}, 6.42 \mathrm{~h}$ and $0.45 \mathrm{~h}$, respectively. These results are highly significant because they show that the enzyme obtained in this study remains active over a very long time period at its optimum temperature $\left(45^{\circ} \mathrm{C}\right)$, as opposed to the earlier isolated $\beta$-galactosidase from $L$. acidophilus with the $24 \mathrm{~h}$ half-life [24].

Table 2. Inactivation constants and half-lives of $\beta$-galactosidase from $L$. acidophilus at different temperatures

\begin{tabular}{cccc}
\hline $\begin{array}{c}\text { Temperature } \\
\left({ }^{\circ} \mathrm{C}\right)\end{array}$ & $\mathrm{kd}_{\mathrm{d}}(1 / \mathrm{h})$ & $\mathrm{t}_{1 / 2}(\mathrm{~h})$ & $\mathrm{R}^{2}$ \\
\hline 50 & 0.005 & 138.6 & 0.9801 \\
55 & 0.108 & 6.42 & 0.9887 \\
60 & 1.542 & 0.45 & 0.9872
\end{tabular}


When the values of the obtained half-lives are compared with literature values for other $L A B \beta$-galactosidases, it can be concluded that the obtained enzyme is inactivated much slower at elevated temperatures. For example, $\beta$-galactosidase from Lactobacillus bulgaricus is highly stable at $37{ }^{\circ} \mathrm{C}$ (half-life is around $147 \mathrm{~h}$ ). However, at higher temperatures $-50{ }^{\circ} \mathrm{C}$ and $60{ }^{\circ} \mathrm{C}$, it is significantly inactivated after a short period of time (half-lives $0.75 \mathrm{~h}$ and $0.045 \mathrm{~h}$ ) under the same conditions [30]. Likewise, $\beta$-galactosidase from Lactobacillus reuteri is completely inactivated after $2 \mathrm{~h}$ incubation at $50{ }^{\circ} \mathrm{C}$ without any stabilizers [29]. Therefore, being able to retain stable at higher temperatures provides an important advantage over other LAB $\beta$-galactosidases in terms of potential applications. Namely, it provides a better contamination control, and it also enables the favorization of the transgalactosylation reaction, bearing in mind that at higher temperatures it increases the solubility of lactose which further has a positive effect on the transgalactosylation yield.

Finally, in view of $\mathrm{pH}$ stability of the $\beta$-galactosidase from $L$. acidophilus, it can be observed (Figure $3 \mathrm{~B}$ ) that the optimum $\mathrm{pH}$ value is around 7 , since after eight hours on $55^{\circ} \mathrm{C}$ a relative activity is still above $50 \%$. Interestingly, this is matched to its optimal $\mathrm{pH}$ value from the aspect of activity. However, moderate stability can be observed at $\mathrm{pH} 6$ (half-life around $4 \mathrm{~h}$ ), while the surroundings of $\mathrm{pH} 5$ and $\mathrm{pH} 8$ are not well suited for the implementation of this enzyme. Hence, it can be concluded that this enzyme can find its application in hydrolysis of milk and sweet whey, rather than acid whey.

\section{Determination of kinetic parameters}

In terms of kinetic parameters determination, two experiments featuring different enzyme substrates (o-NPG and lactose) were conducted. The initial reaction rates at different initial concentrations of the substrate are depicted in Figure 4. From the shape of the curves, it can be seen that the reaction follows simple Michaelis-Menten kinetics. Hence, in order to determine the kinetic parameters $\left(\mathrm{K}_{\mathrm{m}}\right.$ and $\mathrm{V}_{\max }$ ) the double reciprocal (LineweaverBurk) diagram is constructed.

The numerical values of these parameters for the oNPG hydrolysis for $\beta$-galactosidase from $L$. acidophilus were $0.44 \mathrm{mM}$ and $25.64 \mathrm{mM} / \mathrm{h}$, respectively. In the case of lactose hydrolysis, the values of the kinetic parameters were $3.97 \mathrm{mM}$ and $3.10 \mathrm{mM} / \mathrm{h}$, respectively. Similar results for $\beta$-galactosidase from $L$. acidophilus, namely $0.73 \pm 0.07 \mathrm{mM}(\mathrm{Km})$ for o-NPG hydrolysis and $4.04 \pm$ $0,26 \mathrm{mM}(\mathrm{Km})$ for lactose hydrolysis were previously reported in the literature [24]. Based on these parameters, it can be concluded that the obtained $\beta$-galactosidase has a higher affinity towards o-NPG compared to lactose. However, it is important to emphasize that the $\mathrm{Km}$ values obtained for lactose hydrolysis are significantly lower in comparison to other LAB $\beta$-galactosidases (10-40 mM) [29-32], or other commercially available preparations such as Aspegillus oryzae (36-180 mM) [33], Klyvero- myces fragilis (15-52 mM) [33] and Kluyveromyces lactis (35 mM) [33]. These results suggest that the obtained enzyme can have a significant application in the reaction lactose hydrolysis in order to achieve low concentrations of lactose, which is often impossible to achieve by using the existing commercial preparations. Furthermore, in both cases, it may be noted that there is no inhibition by excess substrate, which is often the case with $\beta$-galactosidase isolated from lactic acid bacteria.

Figure 4A

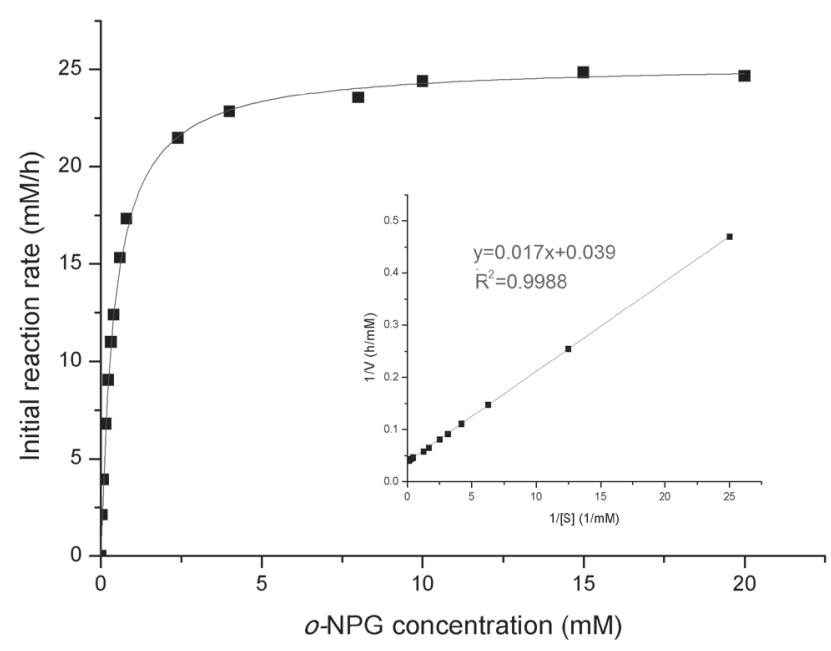

Figure 4B

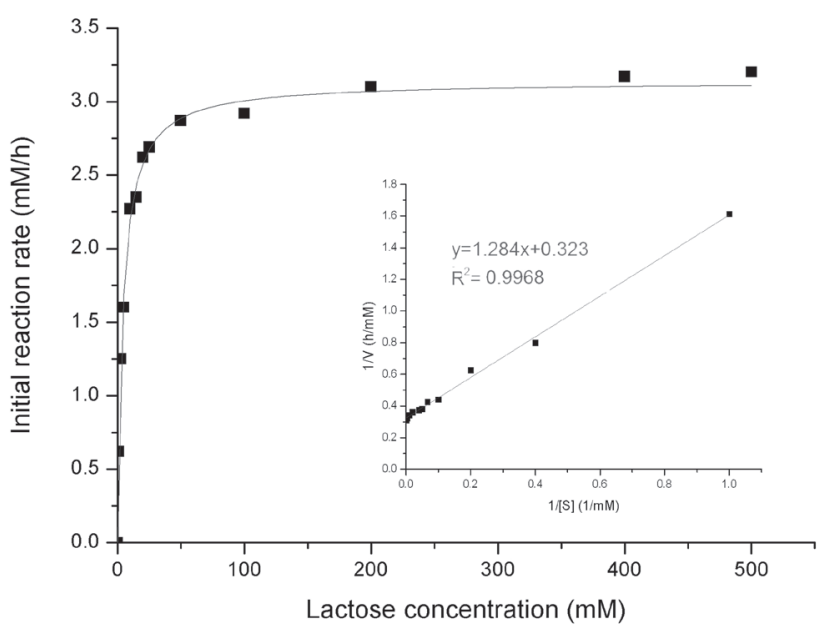

Figure 4. Kinetic study of $\beta$-galactosidase from Lactobacillus acidophilus using o-NPG (A) and lactose $(B)$ as substrates

Effects of different cations on $\beta$-galactosidase activity

Metal ions play an important role in the biological function of the enzyme. They provide many important protein functions such as modification of protein structures, the enhancement of the structural stability of proteins in the conformation required for a biological function, or take part in the catalytic processes acting as the acceptor or an electron donor during the reaction [34]. 
For some enzymes, the presence of metal ions is crucial for the activity. And, on the other hand, some metal ions have a negative effect on the enzyme activity and stability. Therefore, various mono and divalent metal ions (Figure 5) were tested with respect to a possible stimulating or inhibitory effect on $\beta$-galactosidase activity.

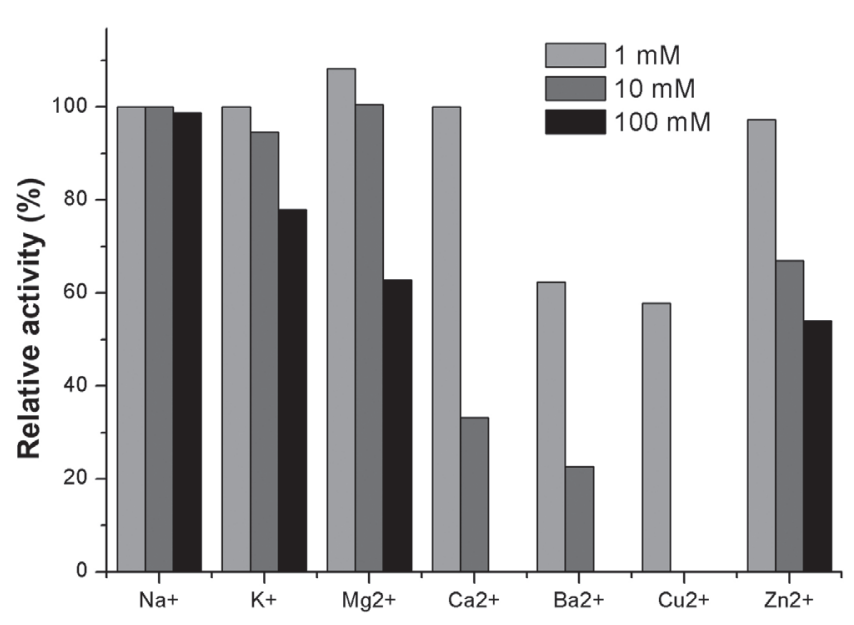

Figure 5. The effect of different metal ions on $\beta$-galactosidase activity

As it can be clearly seen, the monovalent cations $\mathrm{Na}^{+}$ and $\mathrm{K}^{+}$show the negligible influence at lower concentrations (1 $\mathrm{mM}$ and $10 \mathrm{mM})$, while at higher concentrations $(100 \mathrm{mM})$ only $\mathrm{K}^{+}$shows moderate inhibition. On the other hand, it can be noted that $\mathrm{Ca}^{2+}, \mathrm{Ba}^{2+}$ and $\mathrm{Cu} 2+$ have a pronounced inhibitory effect on the activity of $\beta$-galactosidase from $L$. acidophilus, particularly $\mathrm{Cu}^{2+}$ which leads to the complete inactivation of the enzyme at low concentrations $(10 \mathrm{mM})$, while the others provide the inhibitory effect with increasing concentrations. On the other hand, low concentrations of $\mathrm{Mg}^{2+}$ lead to a slight activation of the enzyme. This behavior is not uncommon, given that the $\mathrm{Mg}^{2+}$ ion was previously identified within the active center of the LAB $\beta$-galactosidases, and its supposed function was binding of substrate, substrate analogs and inhibitors [24].

\section{Conclusions}

In this paper, the use of $L$. acidophilus ATCC 4356 for $\beta$-galactosidase production was studied. The progress in utilization of $L$. acidophilus biocatalytic potential was achieved by the response surface methodology optimization of relevant cultivation factors (temperature, inoculum concentration and lactose concentration) in view of $\beta$-galactosidase production. This method proved to be highly useful, since optimized conditions provided the produced activity of $3.12 \mathrm{IU} / \mathrm{ml}$ and the specific activity of $2.64 \mathrm{IU} / \mathrm{mg}$ proteins. The obtained enzyme preparation was further characterized, and it was concluded that the optimum temperature and $\mathrm{pH}$, from the view of both activity and stability were $45^{\circ} \mathrm{C}$ and 6.5 , respectively. The insight into kinetic constants demonstrated the high potential of the obtained enzyme in lactose hydrolysis, and consequently could be utilized as a valuable biocatalyst in the dairy industry.

\section{Acknowledgements}

The research was financed by the Ministry of Education, Science and Technological Development of the Republic of Serbia through funding Project III 46010.

\section{References}

[1] Q. Husain, $\beta$-Galactosidases and their potential applications: A review, Critical Reviews in Biotechnology, 30 (2010) 41-62.

[2] P. S. Panesar, R. Panesar, R. S. Singh, J. F. Kennedy, H. Kumar, Microbial production, immobilization and applications of $\beta$-D-galactosidase, Journal of Chemical Technology and Biotechnology, 81 (2006) 530-543.

[3] A. Illanés, Whey upgrading by enzyme biocatalysis, Electronic Journal of Biotechnology, 14 (2011) 1-28.

[4] X. Y. Chen, M. G. Gänzle, Lactose and lactose-derived oligosaccharides: more than prebiotics? International Dairy Journal, 67 (2017) 61-72.

[5] M. Carević, D. Veličković, M. Stojanović, N. Milosavić, H. Rogniaux, D. Ropartz, D. Bezbradica, Insight in the regioselective enzymatic transgalactosylation of salicin catalyzed by $\beta$-galactosidase from Aspergillus oryzae, Process Biochemistry, 50 (2015) 782-788.

[6] M. G. Ganzle, Enzymatic synthesis of galactooligosaccharides and other lactose derivatives (heterooligosaccharides) from lactose, International Dairy Journal, 22 (2012) 116-122.

[7] P. Urrutia, C. Mateo, J. M. Guisan, L. Wilson, A. Illanes, Immobilization of Bacillus circulans $\beta$-galactosidase and its application in the synthesis of galactooligosaccharides under repeated-batch operation, Biochemical Engineering Journal, 77 (2013) 41-48.

[8] T. Palai, A. Kumar, P. K. Bhattacharya, Kinetic studies and model development for the formation of galactooligosaccharides from lactose using synthesized thermo-responsive bioconjugate, Enzyme and Microbial Technology, 70 (2015) 42-49.

[9] D. F. M. Neri, V. M. Balcão, S. M. Cardoso, A. M. S. Silva, M. D. R. M. Domingues, D. P. M. Torres, L. R. M. Rodrigues, L. B. Carvalho, J. A. C. Teixeira, Characterization of galactooligosaccharides produced by $\beta$-galactosidase immobilized onto magnetized Dacron, International Dairy Journal, 21 (2011) 172-178.

[10] M. Carević, M. Ćorović, M. Mihailović, K. Banjanac, A. Milisavljević, D. Veličković, D. Bezbradica, Galactooligosaccharide synthesis using chemically modified $\beta$-galactosidase from Aspergillus oryzae immobilized onto macroporous amino resin, International Dairy Journal, 54 (2016) 50-57.

[11] D. P. Torres, M. Gonçalves, J. A. Teixeira, L. R. Rodrigues, Galacto-Oligosaccharides: Production, properties, applications, and significance as prebiotics, Comprehensive Reviews in Food Science and Food Safety, 9 (2010) 438-454.

[12] A.-R. Park, D.-K. Oh, Galacto-oligosaccharide production using microbial $\beta$-galactosidase: current state and 
perspectives, Applied Microbiology and Biotechnology, 85 (2010) 1279-1286.

[13] V. Sangwan, S. K. Tomar, R. R. B. Singh, A. K. Singh, B. Ali, Galactooligosaccharides: Novel Components of Designer Foods, Journal of Food Science, 76 (2011) 103-111.

[14] K. Shoaf, G. L. Mulvey, G. D. Armstrong, R. W. Hutkins, Prebiotic galactooligosaccharides reduce adherence of enteropathogenic Escherichia coli to tissue culture cells, Infection and Immunity, 74 (2006) 6920-6928.

[15] J. Vulevic, A. Drakoularakou, P. Yaqoob, G. Tzortzis, G. R. Gibson, Modulation of the fecal microflora profile and immune function by a novel transgalactooligosaccharide mixture (B-GOS) in healthy elderly volunteers, American Journal of Clinical Nutrition, 88 (2008) 1438-1446.

[16] K. Maawia, S. Iqbal, T. R. Qamar, P. Rafiq, A. Ullah, M.U.-D Ahmad, Production of impure prebiotic galactooligosaccharides and their effect on calcium, magnesium, iron and zinc absorption in Sprague-Dawley rats, PharmaNutrition, 4 (2016) 154-160.

[17] G. T. Macfarlane, H. Steed, S. Macfarlane, Bacterial metabolism and healthrelated effects of galactooligosaccharides and other prebiotics, Journal of Applied Microbiology, 104 (2008) 305-344.

[18] B. Splechtna, T. H. Nguyen, D. Haltrich, Comparison between discontinuous and continuous lactose conversion processes for the production of prebiotic galacto-oligosaccharides using $\beta$-galactosidase from Lactobacilius reuter, Journal of Agricultural and Food Chemistry, 55 (2007) 6772-6777.

[19] C. Tari, F. I. Ustok, S. Harsa, Production of food grade $\beta$-galactosidase from artisanal yogurt strains, Food Biotechnology, 24 (2010) 78-94.

[20] A. Nath, S. Mondal, S. Chakraborty, C. Bhattacharjee, R. Chowdhury, Production, purification, characterization, immobilization, and application of $\beta$-galactosidase: $\mathrm{A}$ review, Asia-Pacific Journal of Chemical Engineering, 9 (2014) 330-348.

[21] T. Vasiljevic, P. Jelen, Drying and storage of crude $\beta$-galactosidase extracts from Lactobacillus delbrueckii ssp. bulgaricus 11842, Innovative Food Science and Emerging Technologies, 4 (2003) 319-329.

[22] M. Carević, M. Vukašinović-Sekulić, S. Grbavčić, M. Stojanović, M. Mihailović, A. Dimitrijević, D. Bezbradica, Optimization of $\beta$-galactosidase production from lactic acid bacteria, Hemijska Industrija, 69 (2015) 305-312.

[23] Q. Pan, J. Li, Y. Cong, L. Liu, J. Zhu, F. Hu, Cloning, expression and characterization of a heterodimeric betagalactosidase from Lactobacillus acidophilus ATCC 4356 , Acta Microbiologica Sinica, 48 (2008) 1339-1343.

[24] T. H. Nguyen, B. Splechtna, S. Krasteva, W. Kneifel, K. D. Kulbe, C. Divne, D. Haltrich, Characterization and molecular cloning of a heterodimeric $\beta$-galactosidase from the probiotic strain Lactobacillus acidophilus R22, FEMS Microbiology Letters, 269 (2007) 136-144.

[25] M. M. Bradford, A rapid and sensitive method for the quantitation of microgram quantities of protein utilizing the principle of protein-dye binding, Analytical Biochemistry, 72 (1976) 248-254.

[26] T. U. Nawbueze, Basic steps in adapting response surface methodology as mathematical modelling for bioprocess optimisation in the food systems, International Journal of Food Science and Technology, 45 (2010) 1768-1776.

[27] S. Dagbagli, Y. Goksungur, Optimization of $\beta$-galactosidase production using Kluyveromyces lactis NRRL Y-8279 by response surface methodology, Electronic Journal of Biotechnology, 11 (2008) 1-12.

[28] C. A. Hsu, R. C. Yu, C. C. Chou, Production of $\beta$-galactosidase by Bifidobacteria as influenced by various culture conditions, International Journal of Food Microbiology, 104 (2005) 197-206.

[29] T. H. Nguyen, B. Splechtna, M. Steinböck, W. Kneifel, H. P. Lettner, K. D. Kulbe, D. Haltrich, Purification and Characterization of Two Novel $\beta$-Galactosidases from Lactobacillus reuteri. Journal of Agricultural and Food Chemistry, 54 (2006) 4989-4998.

Izvod

\section{PRODUKCIJA I KARAKTERIZACIJA $\beta$-GALAKTOZIDAZE IZ LACTOBACILLUS ACIDOPHILUS}

Milica B. Carević, Maja S. Vukađinović Sekulić, Katarina M. Banjanac, Ana D. Milivojević, Marija M. Ćorović, Dejan I. Bezbradica

Katedra za biohemijsko inženjerstvo i biotehnologiju, Tehnološko-metalurški fakultet, Univerzitet u Beogradu, Beograd, Srbija

$\beta$-Galaktozidaza je značajan industrijski enzim koji se tradicionalno koristi za katalizovanje reakcije hidroloze laktoze, ali poslednjih godina nalazi i sve značajniju primenu u reakcijama sinteze različitih bioaktivnih galaktozida. $U$ ovoj studiji, ispitani su optimalni uslovi za postizanje visokih prinosa $\beta$-galaktozidaze iz Lactobacillus acidophilus ATCC 4356, bakterije mlečne kiseline koja se smatra bezbednom za korišćenje u prehrambenim proizvodima. Statističkim planiranjem eksperimenata i metodom odzivnih površina, zaključeno je da se najveća aktivnost i specifična aktivnost dobijaju nakon dvodnevne fermentacije na temperaturi od $28^{\circ} \mathrm{C}$, kada je koncentracija laktoze $1,48 \%$, a koncentracija inokuluma $2,80 \%$. Temperaturni i pH optimum dobijenog enzima iznose $45^{\circ} \mathrm{C}$ i 6,8 , redom, pri čemu ovi uslovi istovremeno omogućuju i izuzetnu stabilnost enzima. U kinetičkoj studiji određene su vrednosti kinetičkih parametara, $\mathrm{Km}_{\mathrm{m}}$ И $\mathrm{V}_{\max }$ : 0,44 $\mathrm{mM}$ i 25,64 mM/h (za o-nitrofenil$\beta$-D-galaktopiranozid), odnosno 3,79 mM i 3,10 mM/h (za laktozu). Takođe, nije primećena inhibicija supstratom u višku, dok se enzim inaktivira u prisustvu jona $\mathrm{Ca}^{2+}, \mathrm{Ba}^{2+}, \mathrm{i} \mathrm{Cu}^{2+}$.
(ORIGINALNI NAUČNI RAD) UDK 577.152.3:579.86:547.458.5

Ključne reči: $\beta$-galaktozidaza, Lactobacillus acidophilus, proizvodnja enzima, metoda odzivnih površina 